\title{
EFFECTS OF SCALING AND ROOT PLANING WITH OR WITHOUT ORAL HYGIENE MEASURES ON THE TREATMENT OF CHRONIC PERIODONTITIS: AN IMMUNOHISTOCHEMICAL AND CLINICO-BIOCHEMICAL STUDY
}

\author{
Nehad S. Taha*, Mohamed Zayed*** and Ahmed Mahmoud A. Aziz***
}

\begin{abstract}
Periodontal disease involves complex interactions between bacterial products; host cells and locally produced biologically active factors. The role of cytokines, IL-1 beta and IL-6, in periodontal disease pathogenesis has been widely reported. In this study, we studied the role of periodontal treatment with and without oral hygiene measures through measuring the level of these cytokines in cervical gingival fluid and in gingival tissues. The study results demonstrated that the level of cytokines decreased after dental treatment without application of oral hygiene measures, but their levels decreased significantly if the dental treatment was associated with oral hygiene measures. This indicated that oral hygiene measures are important for better chronic periodontitis treatment.
\end{abstract}

KEYWORDS: Chronic periodontitis, cytokines, gingival crevicular fluid, oral hygiene measures, immuno-expression.

\section{INTRODUCTION}

Chronic periodontitis is the most prevalent form of periodontitis, which affects a majority of the adult population and causes tooth loss (Hugoson et al 2008). The expression of the disease results from the interaction of host defense mechanisms, microbial agents, environmental, and genetic factors. Tissue destruction that occurs during the disease process results in the release of various inflammatory mediators: cytokines induced and secreted by many cells, such as monocytes (Daniels et al 1992), lymphocytes (Lawlor et al 1992), fibroblasts (Golds et al 1989), epithelial and endothelial cells. (Smith et al 1993, Kwon et al 1994) as well as by synovial cells such as interleukin-1alpha (IL-1 $\alpha$ ), interleukin-1beta (IL-1 $\beta$ ), interleukin-6 (IL-6) and interleukin-8 (IL-8) (Haba et al 2011; Otenio et al.; 2012, Masamatti et al 2012; Raghavendra et al 2012, Xynogala et al 2012), tumor necrosis factor-alpha,

\footnotetext{
* Associate Professor of Oral Biology Department, Faculty of Oral \& Dental Medicine, Misr International University (MIU) ** Associate Professor of Oral Biology Department, Faculty of Oral \& Dental Medicine, Misr International University (MIU) ****ecturer of Oral Medicine and Periodontology Department, Faculty of Oral \& Dental Medicine, Misr International University (MIU)
} 
and prostaglandin $E_{2}$, which play a role in the loss of connective tissue as well as the supporting alveolar bone (Genco et al 1992). These inflammatory mediators show variation in the concentration with the severity of periodontitis (Mombelli et al 1997).

IL-1 $\beta$, IL-6 in co-operation with other inflammatory mediators has an important role in regulating and amplifying the inflammatory response in periodontal tissues (Panagakos et al 1996, Delaleu et al 2004). A high level of IL-1 $\beta$ and IL-6 in the gingival crevicular fluid (GCF) (Masada et al 1990, Honig et al 1989) and the gingival tissue (Stashanko et al 1991, Orozco et al 2006) have been associated with chronic periodontitis.

Periodontal diagnosis and treatment plan are based on the assessment of probing depth, clinical attachment level, plaque index, gingival index, bleeding on probing, mobility, and radiographic findings. However, these clinical parameters are not sufficiently sensitive and specific to identify disease activity in individual sites or to predict future attachment loss. Hence, attention is focused on the development of diagnostic tools that could detect the active inflamed sites and predict future tissue destruction (2014 Raed et al).

Gingival crevicular fluid (GCF) is a complex mixture of substances derived from serum, host inflammatory cells, structural cells of the periodontium, and oral bacteria. GCF originates from the vessels of the gingival plexus of blood vessels and flows through the external basement membrane and the junctional epithelium to reach the gingival sulcus. GCF can be isolated from healthy sulcus, although only in small amounts. In the healthy periodontium, GCF represents the transudate of gingival tissue interstitial fluid produced by an osmotic gradient (Alfano 1974). The products of the inflammatory response which occur during the disease process can be found in the GCF. Monitoring of the presence of such components can be of potential value in evaluating periodontal disease status or outcomes of periodontal therapy (Toker et al 2006). Apart from this, GCF collection is a noninvasive and relatively simple procedure to perform (Uitto 2003).

Prevention of, and early intervention into periodontal disease is critical, and oral hygiene education is central to all stages of treatment. In addition to professional care, successful management of periodontal disease depends on the capacity of patient's oral self-care (Löe 2000, Axelsson et al 2004, Magdalena et al 2015). A change in patient attitude and behavior is often desirable when periodontitis is treated. The information gathered relative to a patient's values and beliefs may be a useful guide in designing effective oral health care interventions (Vick et al 2000).

In order to plan effective interventions which encourage patient self-care, it is first important to collect basic information regarding self-care behavior and perception. Currently, there is no universally accepted or recommended assessment tool for oral health behavior of periodontitis patients. Because of the limited amount of time available at clinical appointments, utilizing complex instruments based on health behavior models may not always be practical. Thus, there is a need for concise assessment of such data (2009 Atsushi et al).

Oral diseases adversely affect concentration, interpersonal relationship, and productivity due to the intricate relationship between oral health and general health. Prevention of oral disease can be achieved by optimizing the oral health practices in the form of proper tooth brushing, use of dental floss, dental visits at regular intervals, and proper dietary practices (Azodo et al 2012).

The clinical concept that the maintenance of an effective plaque control is the cornerstone of any attempt to prevent and control periodontal diseases established since 1950s still remains valid (Johani 2008). The understanding of actual practices in keeping the oral heath at standard based on patients' 
perceptions of oral health care is vital. Oral health is about more than shining white teeth and sweet breath. The practices and perceived access barriers have been related to oral health (Marsh 2012). Patient's perception of the quality of dental care provision and their intent on re-accessing a dental service may be associated with a practitioner's professionalism, empathy, and delivery of oral hygiene advice (Saleh et al 2011).

The purpose of this study was to examine the effect of periodontal treatment with and without educational program (oral hygiene measures) by measuring the levels of IL- $1 \beta$ and IL- 6 in periodontally diseased individuals in cervical fluid and IL-6 in gingival tissues through histological and immunohistochemical studies.

\section{SUBJECTS AND METHODS}

Sixty five patients with chronic periodontitis were recruited into this randomized, interventional study, at the Misr International University periodontal clinic. For each patient, a detailed verbal and written description of the study was given and a signed consent form was obtained prior to enrolment in this study, and the study was following the university regulations. The selection criteria were (1) the age range from 22 to 61 for both males and females. (2) good general health with no history of systemic diseases; (3) no medication was taken; (4) no periodontal therapy received in the preceding 2 years; (5) more than 24 remaining teeth; (6) mild to moderate periodontal disease as evidenced by multiple sites with a CAL of $4 \mathrm{~mm}$ or more, and bleeding on gentle probing; (7) pregnant or lactating females were excluded. Postmenopausal females or others on estrogen therapy were also excluded (Vinayak 2014).

The patients in this study were divide into: (group 1) were 14 patients: 8 males and 6 females with their mean age 32.11 with a moderate to severe form of chronic periodontitis receiving oral hygiene measures and periodontal treatment. (Group II) were 17 patients: 8 male and 9 female with their mean age is 33.7 with moderate to severe form of periodontitis receiving periodontal treatment only. The control group (group III) was 19 clinically healthy subjects (15 males and 4 females) and mean age 37.4 showing also moderate to severe form of periodontitis not receiving both dental treatment or oral hygiene measures. Group IV were 15 patients 6 male and 9 female and the mean age 30.12 showing also moderate to severe form of periodontitis receiving oral hygiene measures only.

In each patient, two quadrants of either the mandible or maxilla were randomly assigned as experimental. In each experimental quadrant, 4 periodontal interproximal sites were evaluated. Two or more sites displaying probing pocket depths (PD) $\geq 4 \mathrm{~mm}$ and a gingival index 2 or more (GI) (Siamak etal 2013) were defined as diseased tooth with periodontitis and 3 sites with PD $\leq 3 \mathrm{~mm}$ and $\mathrm{GI}=0$ or 1 was defined as a non-diseased tooth.

For group I \& II, diseased sites received periodontal treatment consisting of scaling and root surface debridement (SRP). Six weeks following treatment, Gingival biopsies (one per person) were harvested from all groups during routine gingivectomy and gingivoplasty procedures while for clinically healthy subjects (group III) gingival biopsies were taken from gingival collar from a hopeless badly decayed tooth, with clinically healthy periodontium, indicated for extraction.

\section{Histological and Immunohistochemistry examination}

The forty two paraffin embedded tissue $4-\mu \mathrm{m}$ thick sections were obtained and stained with hematoxylin-eosin (H\&E).

For immunohistochemistry, 4- $\mu$ m thick sections were mounted on positively charged slides, immuno-stained with anti-IL-6 antibody with super sensitive biotin-streptavidin staining technique. Tissue sections were de-parafinized, rehydrated 
and treated with $3 \% \mathrm{H}_{2} \mathrm{O}_{2}$ for 10 min to block the endogenous peroxidase activity. For antigen retrieval, the slides were boiled in $10 \mathrm{~m} \mathrm{M}$ citrate. buffer, pH 6.0 in an autoclave which its temperature is adjusted at $120^{\circ} \mathrm{C}$ and maintained stable for 15 min followed by cooling at room temperature for 30 min. Background staining was blocked by putting 2-3 drops of $10 \%$ goat non immune serum blocker on each slide and incubating them in a humidity chamber for $10 \mathrm{~min}$. Without washing, excess serum was drained from each slide The positive test slides were incubated with the primary mouse monoclonal anti-IL-6 antibody (Clone UJ127, Thermo Scientific, Labvision, USA)with the appropriate dilution range 1:100for I hour at room temperature in a humified chamber. On the other hand, the negative control slides were not exposed to the primary antibody.

After washing with phosphate buffer solution (PBS), the slides were treated with the biotin labeled link antibody, then the streptavidin conjugated to horseradish peroxidase was used. The diaminobenzedine (DAB) chromogen was applied to visualize the antigen antibody reaction. All these reagents belong to the universal Labeled Streptavidin-Biotin 2 System, Horseradish Peroxidase (code no.K0673 DakoCytomation, Denmark).

All the slides were immersed in Mayer's hematoxylin for counterstaining. Finally, the sections were covered by cover slips using aqueous mounting medium.

\section{Immunohistochemical Evaluation}

The ordinary light microscope was used to detect and localize the IL-6 immuno-staining. Cells with cytoplasmic and/or membranous staining were considered positive. Then, all the sections were examined by an image analyzer computer system using the software Leica Queen 500. Five random fields in each specimen were captured using a magnification (X400) to determine the area percentage and immuno-staining intensity of the positive tumor cells.
The area percentage and immuno-staining intensity were scored according to the difference between the largest and smallest mean value of each parameter in the studied cases.

\section{Statistical analysis}

The concentrations of mRNA and the total scores of immuno-expression of IL- 6 of the studied groups of specimens were represented as mean values and standard deviations (SD) for statistical evaluation. The ANOVA test was used to compare the mean values of mRNA concentrations among the studied groups. Student t-test was used to compare the mean values of the total score of IL$1 \beta$ and IL-6 expression in gingival crevicular fluid.. At $95 \%$ confidence interval, $p$ value was considered significant when $\mathrm{p}<0.05$.

\section{Detection of IL-1 $\beta$ and IL-6 in gingival crevicular fluid}

Clinical parameters: the plaque index (PI) (Silness et al 1964), gingival index (GI) (Loe et al 1963), was recorded before GCF sampling and these values were used in analysis.

The selected test site was air-dried and isolated with sterile cotton rolls. The GCF was collected by using a non-invasive technique (Offenbacher et al., 1981), a standard volume of $2 \mu \mathrm{L}$ was collected, a white color-coded, 1- to 5- $\mu \mathrm{L}$ calibrated volumetric microcapillary pipette (Sigma-Aldrich Chemie Gmbh, Munich, Germany). The collected GCF samples were immediately transferred to the sterile Eppendorf tubes containing $98 \mu \mathrm{L}$ of buffered alkaline phosphate saline and were immediately transported to the laboratory, where they were stored at $-80^{\circ} \mathrm{C}$ until the time of assay. Only the samples that were not visibly contaminated with blood or plaque were considered for the study.

IL- $1 \beta$ and IL-6 were assayed, according to the manufacturer's instructions, by enzyme immunoassay (EIA) using kits provided from Biosource, Cambridge (USA) and Predicta Genozyme, Cambridge (USA) respectively. The concentrations were expressed in $\mathrm{ng} / \mathrm{ml}$ (Tasi, et al. 1995). 


\section{Tools of oral hygiene measures}

A constructed interviewing questionnaire was designed for patients at out clinic including socio demographic data (age, sex, educational level, occupation, income), personal history, present and past history, medical history and aim of daily oral hygiene. The questionnaire and its purpose were explained to the patients.

Oral hygiene measures was divided into sessions; each session took about 20-30 minutes and was applied once per week along a period of six weeks. The program depended upon prepared equipment using power point, and posters.

Evaluation: After six weeks, clinical examination was done, and the chemical analysis of inflammatory mediators was repeated.

\section{RESULTS}

\section{Histological results}

\section{Group I:}

Gingiva subjected to dental treatment and oral hygiene measures show normal keratinized stratified squamous epithelium with long, thin and irregular rete pegs and thin keratin layer (Fig. 1a). Some of basal and lower layer of spinous cell layer show many mitotic figures (Fig. 1b), the prickle cell layer is clear with intact cell wall (Fig. 1b). The connective tissue layer appears normal with small and thin walled blood vessels and few inflammatory cells. The collagen fibers are thin and irregular in arrangement (Fig 1).

\section{Group II:}

Gingiva subjected to dental treatment only without oral hygiene measures application show thick dense collagen bundles in the lamina propria (Fig. 2). The connective tissue reveals many inflammatory cells under basement membrane and few dispersed inflammatory cells between collagen fibers, few epithelial cells show pyknotic nuclei, vacuolization (Fig. 2).

\section{Group III:}

Gingiva not subjected to dental treatment or oral hygiene measures show intense and profound inflammatory cell infiltration, blood vessels dilatation. Few epithelial cells show pyknotic nuclei while others show vacuolization and degeneration (Fig. 3a). Other area shows moderate to severe extravasation of red blood cells with ruptured blood vessels, with enlargement of some epithelial cells. (Fig. 3b)

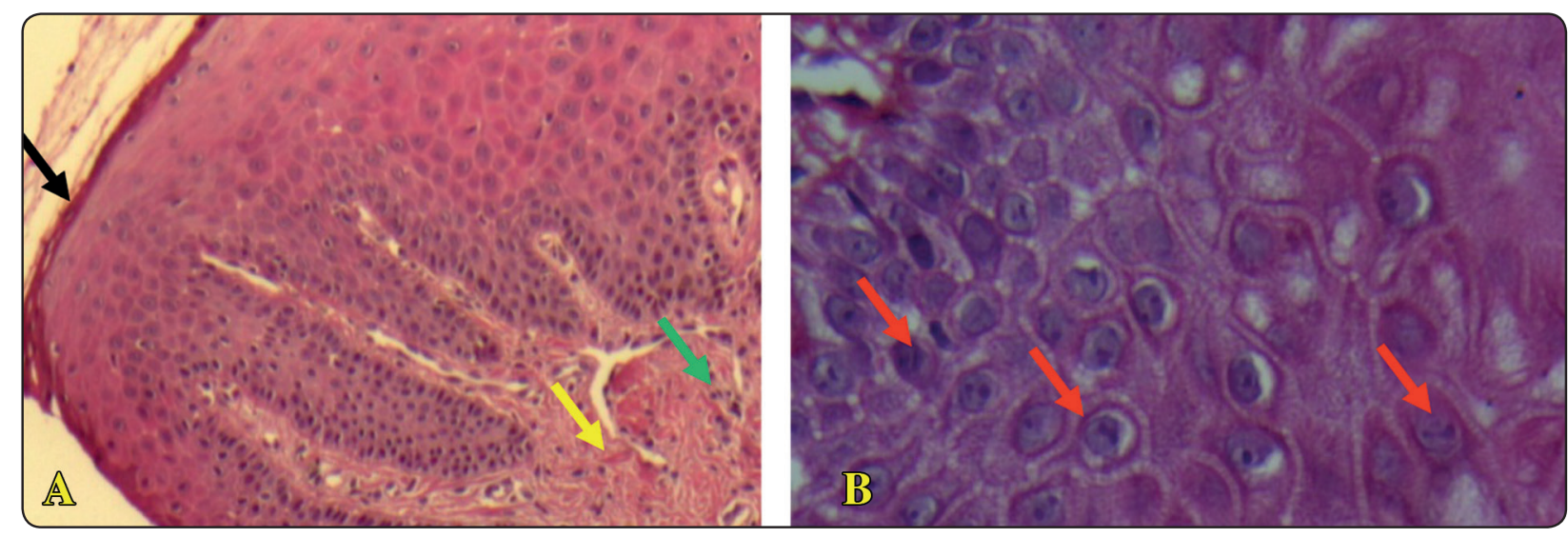

Fig. (1) A photo micrograph of group I showing a) normal healthy epithelium and long, thin \& irregular rete pegs with thin keratin layer (black arrow). There are small and narrow blood vessels in lamina propria (yellow arrow), few inflammatory cells (green arrow). (H\&E. x 100), b) many dividing cells (red arrows) in basal and para-basal layer with clear intercellular spaces (H\&E x 400) 


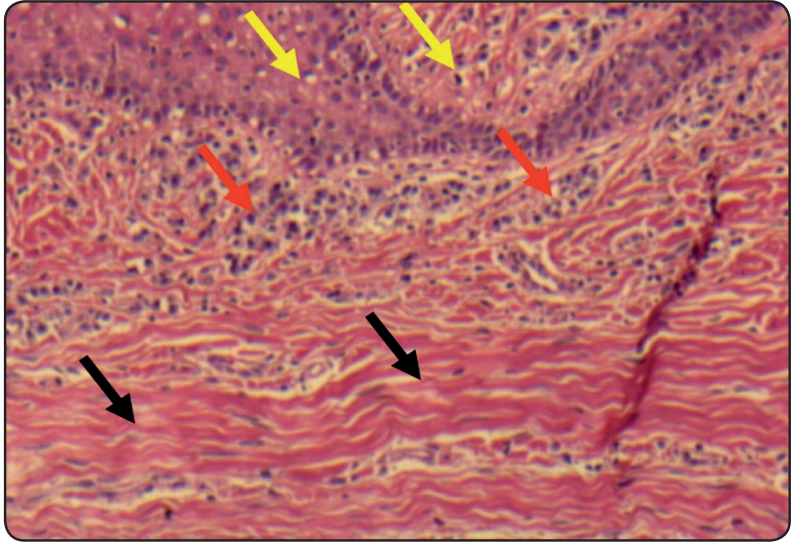

Fig. (2) A photomicrograph of group II showing dense collagen bundles (black arrow), increased sub-epithelial inflammatory cells (red arrows), and some epithelial cells show vacuolization and pyknotic nuclei (yellow arrows). (H\&E x200).

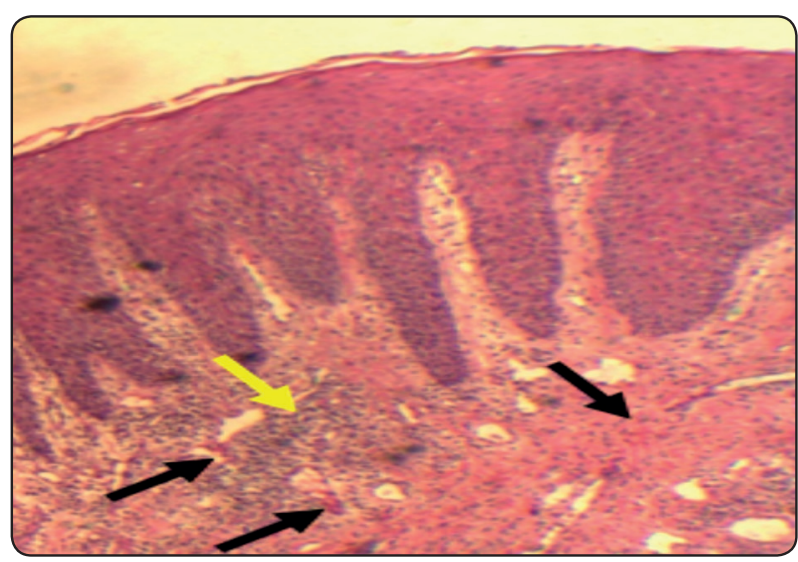

Fig. (4) A photo micrograph of group IV revealing chronic inflammatory cell aggregation in lamina propria (yellow arrows), increased vascularity (black arrows). (H\&E. x 200)

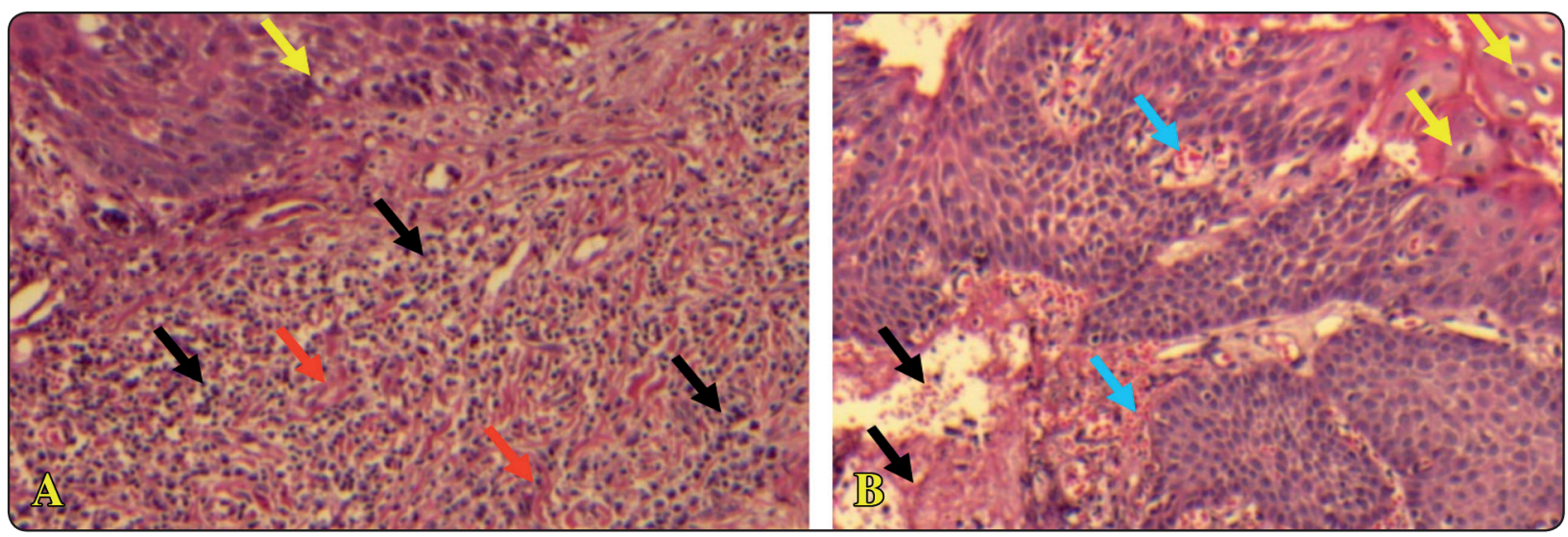

Fig. (3) A photo micrograph of group III a) showing intense inflammatory cells in connective tissue (black arrows), many dilated blood vessels (red arrows), epithelial cells show vacuolization and pyknotic nuclei (yellow arrows). b) Showing rupture of blood vessel with extravasation of red blood cells (blue arrows), degenerated and necrotic areas (black arrow), enlarged pyknotic epithelial cells (yellow arrows).(H \&E. x 100)

\section{Group IV:}

Group IV, following oral hygiene measures only, shows aggregation of chronic inflammatory cells in lamina propria. Long irregular epithelial rete pegs, and increased vascularity (Fig. 4).

\section{Immunohistochemical results}

Negative to weak IL-6 expression was detected in $90 \%$ cases of the group I (Fig 5a). While in $66 \%$ cases of group II demonstrated mild to moderate reaction to IL-6 especially in and around blood vessels (Fig 5b). On the other hand, group IV revealed moderate to strong IL-6 reaction in $74 \%$ of cases (Fig 5c), and strong to intense reaction was detected in the inflammatory cells of the lamina propria I group III (Fig 5d). 


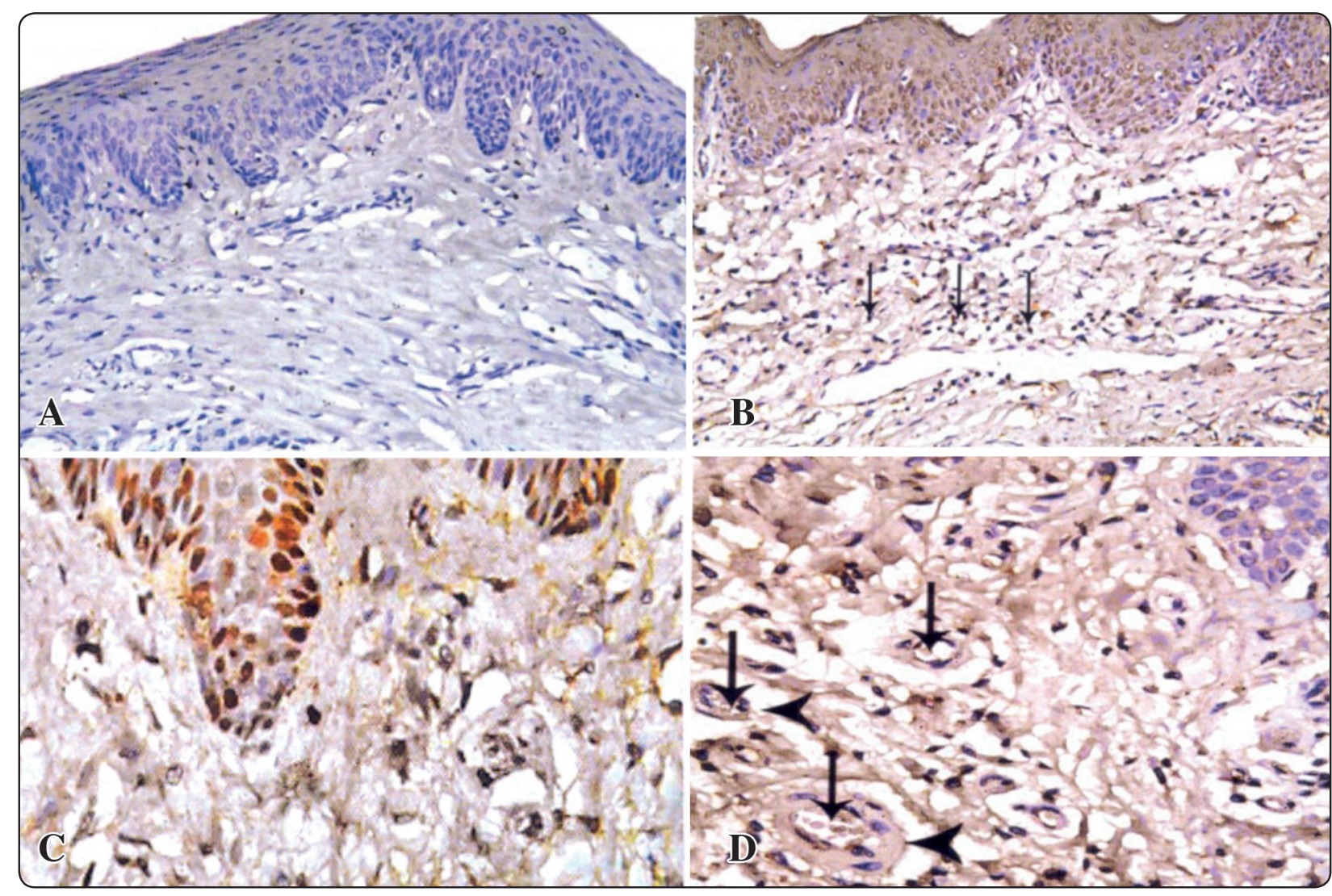

Fig. (5) A photo micrograph of IL-6 stain revealing: (a) weak to negative expression in group I, (b) mild to moderate expression in group II (black arrows), (c) moderate expression in the inflammatory cells with strong basal cells expression in group IV (black arrows), (d) strong to intense expression of inflammatory cells in and around blood vessels in group III (black arrows). (H\&E. x 200)

\section{Clinical results}

Sixty five periodontitis patients were studied, with age ranging from 25 - 45 years (mean age: $32.11 \pm 2.45$ years for the group I; $33.7 \pm 1.7$ years for group II; $37.4 \pm 2.6$ for group III; $30.12 \pm 2.24$ for group IV). No significant statistical difference in age or gender existed between the patients in the four studied groups.

The PD showed statistical significant difference in group I between the baseline and after six weeks, while no significant difference was demonstrated in the other three groups.

CAL demonstrated significant difference in groups II, III, and IV at baseline and after six weeks.
While in group I there was no significant difference.

PI revealed statistical significant difference in groups I, II, and III at baseline and after six weeks. Whereas group IV there was no statistical significant difference.

GI reading revealed only a statistical significant difference in group III between baseline and after six weeks.

The studied periodontal indices revealed lower PD \& CAL readings, together with PI and GI scores of the three studied groups as compared to group III (healthy control) after six weeks as demonstrated in table 1 . 
The GCF IL-1 $\beta$ in was $(72.22 \pm 6.7)$ in group I at baseline and became significantly lower after both dental treatment and oral hygiene measures application (24.1 \pm 2.7$)$. In group II, who received dental treatment only it was $(54.24 \pm 3.1)$, and was significantly less than same group before dental treatment (70.20 \pm 1.3$)$.As for group IV, it was higher before application of oral hygiene (71.26 \pm 1.3$)$ and decreased after oral hygiene measures $(60.12 \pm 1.3)$. Moreover there was no significant difference between group III measurements at baseline $(70.3 \pm 1.3)$ and after six weeks (72.5. \pm 6.7$)$.

Furthermore, the GCF IL-6 in group I (75.2 \pm 6.6$)$ was significantly lesser than same group before dental treatment $(147.2 \pm 9.2)$, in group II it was $(146.2 \pm 6.3)$ was significantly higher than after treatment (100.2 \pm 8.6$)$. As for group IV, it was significantly lesser after application of oral hygiene measures (60.12 \pm 5.2$)$. Moreover, there was no significant difference between group III measurements at the baseline $(146.2 \pm 6.3)$ and after six weeks $(150.3 . \pm 12.8)$ as demonstrated in table 2, and Fig 6 .

TABLE (1) Clinical characteristics of periodontitis in all groups at baseline and after six weeks (mean \pm SD).

\begin{tabular}{|c|c|c|c|c|c|c|c|c|}
\hline $\begin{array}{l}\text { Groups } \\
\text { Parameters }\end{array}$ & \multicolumn{2}{|c|}{$\begin{array}{l}\text { Group } 1 \\
(\mathrm{n}=14)\end{array}$} & \multicolumn{2}{|c|}{$\begin{array}{l}\text { Group II } \\
(n=17)\end{array}$} & \multicolumn{2}{|c|}{$\begin{array}{c}\text { Group III } \\
(n=19)\end{array}$} & \multicolumn{2}{|c|}{$\begin{array}{l}\text { Group 1V } \\
(\mathrm{n}=15)\end{array}$} \\
\hline Age (years) & \multicolumn{2}{|c|}{$32.11 \pm 2.45$} & \multicolumn{2}{|c|}{$33.7 \pm 1.7$} & \multicolumn{2}{|c|}{$37.4 \pm 2.6$} & \multicolumn{2}{|c|}{$30.12 \pm 2.24$} \\
\hline \multirow[t]{2}{*}{ Males/Females } & \multicolumn{2}{|c|}{$8 / 6$} & \multicolumn{2}{|c|}{$8 / 9$} & \multicolumn{2}{|c|}{$15 / 4$} & \multicolumn{2}{|c|}{$6 / 9$} \\
\hline & Before & After & Before & After & Before & After & Before & After \\
\hline $\begin{array}{l}\text { Mean probing } \\
\text { depth (PD mm) }\end{array}$ & $3.82 \pm 0.3^{*}$ & $\begin{array}{c}1.61 \pm \\
0.2^{*}\end{array}$ & $3.6 \pm 0.4$ & $2.4 \pm 0.5$ & $4.6 \pm 0.6$ & $5.7 \pm 0.6$ & $4.2 \pm 0.2$ & $3.7 \pm 0.6$ \\
\hline $\begin{array}{l}\text { Mean relative } \\
\text { attachment level } \\
(\mathrm{CAL} \mathrm{mm})\end{array}$ & $\begin{array}{c}2.28 \pm \\
0.01\end{array}$ & $\begin{array}{c}1.89 \pm \\
0.01\end{array}$ & $\begin{array}{c}2.24 \pm \\
0.35^{*}\end{array}$ & $\begin{array}{c}2.37 \pm \\
0.47^{*}\end{array}$ & $3.24 \pm 0.65^{*}$ & $\begin{array}{l}3.11 \pm \\
0.19^{*}\end{array}$ & $\begin{array}{c}2.775 .24 \pm \\
0.32^{*}\end{array}$ & $\begin{array}{c}2.281 \pm \\
0.71^{*}\end{array}$ \\
\hline Plaque index & $\begin{array}{l}1.24 \pm \\
0.63^{*}\end{array}$ & $\begin{array}{l}1.01 \pm \\
0.49^{*}\end{array}$ & $\begin{array}{l}1.75 . \pm \\
0.17^{*}\end{array}$ & $\begin{array}{l}1.63 \pm \\
0.29^{*}\end{array}$ & $2.84 \pm 0.25^{*}$ & $\begin{array}{c}2.99 \pm \\
0.37^{*}\end{array}$ & $1.9 \pm 0.7$ & $1.7 \pm 0.4$ \\
\hline$\%$ sites with plaque & $24.2 \pm 4.6$ & $16.7 \pm 4.6$ & $30.1 \pm 0.9$ & $27.1 \pm 0.3$ & $40.2 \pm 6.5^{*}$ & $51.2 \pm 4.4^{*}$ & $37.2 \pm 0.3$ & $39.7 \pm 0.5$ \\
\hline Mean GI & $1.19 \pm 0.3$ & $1.02 \pm 0.4$ & $1.4 \pm 0.2$ & $1.22 \pm 0.6$ & $2.3 \pm 0.6^{*}$ & $2.5 \pm 0.3^{*}$ & $1.5 \pm 0.6$ & $1.27 \pm 0.2$ \\
\hline
\end{tabular}

* = Significant at $P<0.05$

TABLE (2) IL-1 $\beta$ and IL-6 (ng/ $\mu$ l) in gingival crevicular fluid at baseline and after six weeks (mean \pm SD).

\begin{tabular}{|c|c|c|c|c|c|c|c|c|}
\hline $\begin{array}{c}\text { Groups } \\
\text { Parameters }\end{array}$ & \multicolumn{2}{|c|}{ Group 1 } & \multicolumn{2}{c|}{ Group II } & \multicolumn{2}{c|}{ Group III } & \multicolumn{2}{c|}{ Group IV } \\
\hline & Before & After & Before & After & Before & After & Before & After \\
\hline IL-1 $\beta$ & $72.22 \pm 4.1^{*}$ & $24.1 \pm 2.1^{*}$ & $70.20 \pm 1.3^{*}$ & $54.24 \pm 3.1^{*}$ & $70.30 \pm 1.3^{*}$ & $73.5 \pm 6.7^{*}$ & $71.26 \pm 5.3$ & $60.12 \pm 5.2$ \\
\hline IL-6 & $147.4 \pm 9.2^{*}$ & $75.2 \pm 6.6^{*}$ & $146.2 \pm 6.3^{*}$ & $100.2 \pm 8.6^{*}$ & $146.2 \pm 6.3^{*}$ & $150.3 \pm 12.8^{*}$ & $149.3 \pm 10.7$ & $120.3 \pm 9.3$ \\
\hline
\end{tabular}

* Significant difference at $P<0.05$ 


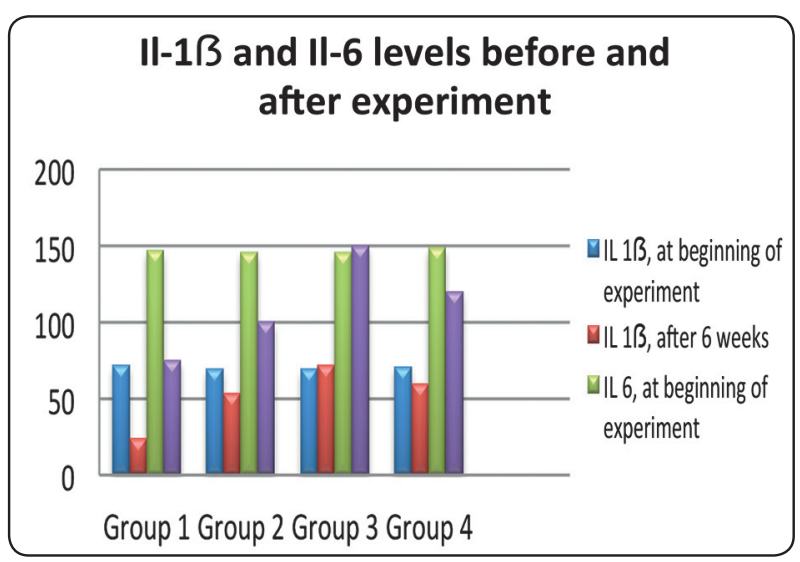

Fig. (6) Graph representing difference in the IL-1 $\beta$ and IL-6 in the crevicular fluid at baseline and after six weeks.

\section{Statistical results}

The image analysis of IL-6 stained gingival sections demonstrated marked difference in the stain intensity and area percentage between the four studied groups, with the least intensity in group I and the highest intensity in group III, while group II demonstrated mild expression and group IV demonstrated moderate expression.

ANOVA test revealed that the difference between group III and the three other groups was statistically significant $(\mathrm{P}<0.05)$ as demonstrated in table $(3,4)$ and figure (7).

TABLE (3) Mean IL-6 expression intensity in the four studied groups after six weeks.

\begin{tabular}{|c|c|c|c|c|}
\hline Variables & Group I & Group II & Group III & Group IV \\
\hline $\begin{array}{c}\text { Number of } \\
\text { samples }\end{array}$ & 5 & 5 & 5 & 5 \\
\hline Mean & 2.181 & 4.333 & $8.16^{*}$ & 6.155 \\
\hline $\begin{array}{c}\text { Standard } \\
\text { deviation }\end{array}$ & 0.317 & 0.384 & $0.94 *$ & 0.688 \\
\hline P value & $<0.005$ & & & \\
\hline
\end{tabular}

* Significant at $P \leq 0.05$
TABLE (4) Mean IL-6 area percentage in the four studied groups after six weeks.

\begin{tabular}{|c|c|c|c|c|}
\hline $\begin{array}{c}\text { Statistical } \\
\text { profile }\end{array}$ & Group I & Group II & Group III & Group IV \\
\hline Mean \pm SD & $1.78 \pm 1.63$ & $2.91 \pm 1.9$ & $5.1 \pm 1.67 *$ & $3.71 \pm 2.1$ \\
\hline $\begin{array}{c}\text { ANOVA } \\
\text { test }\end{array}$ & \multicolumn{3}{|c|}{6.41} \\
\hline P-value & $<0.001^{*}$ \\
\hline
\end{tabular}

* Significant at $P \leq 0.05$

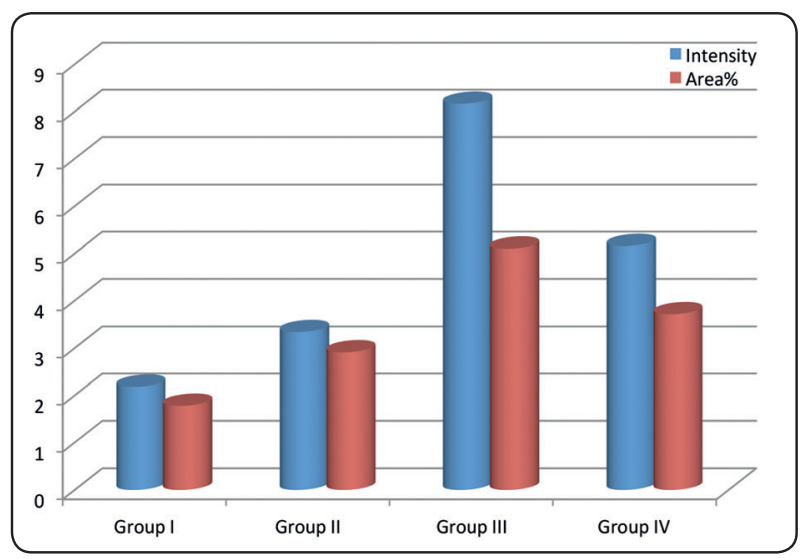

Fig. (7) Graph representing the mean IL-6 intensity and area \% between the four studied groups after six weeks.

\section{DISCUSSION}

As a fact, periodontal diseases result from interactions between specific subgingival microbial species and the susceptible host, leading to the release of inflammatory mediators which in turn mediate tissue destruction. The host immune responses to subgingival biofilms are conducted by cytokines. These molecular messengers are elements of effective innate and adaptive responses and cause fine tuning of the interplay among the different components of the immune system. There are many cytokines, such as IL- $1 \beta$, IL- $1 \alpha$, IL- 6 and tumor necrosis factor $\alpha(\mathrm{TNF} \alpha)$, which have an important role in the inflammatory process (Gowen et al 1983, Stashenko et al 1987, Bertolini et al 1986). 
Interleukin-1 $\beta$ (IL-1 $\beta$ ) is one of the most important cytokines which seems to have an important role in the inflammatory process in gingival and periodontal tissues that stimulates bone resorption (Dewhirst et al 1985, Sabatini et al 1988) and inhibits bone formation (Nguyen et 1991, Konig et al 1988). IL-1 $\beta$ is expressed by many cells and has multiple functions one of them is local inflammation. Cells known to express IL- $1 \beta$ include astrocytes, fibroblasts, hepatocytes, keratinocytes, brown fat adipocytes, $\mathrm{T}$ cells and eosinophils, dendritic cells, macrophages, monocytes (Dinarello 2009).

IL-6 is a pro-inflammatory cytokine produced by a variety of cells including fibroblasts, macrophages, endothelial cells, and keratinocytes in response to induction by variety of stimuli such as infectious agent, endotoxin, wounding (Bals et al 1998). Keratinocytes can synthesize and release significant amounts of IL-6 that are capable of modulating the inflammatory and immune responses (Grone 2002). Moreover, IL-6 isn't expressed by normal human keratinocytes except in various inflammatory disorders. Studies on the role-played by IL-6 in this process have mainly focused on its expression at sites of periodontal inflammation. Most studies report a correlation between disease activity and levels of IL-6 expressions in gingival tissue. This increased expression, along with its reported bone resorptive properties, suggests that IL-6 plays a central role in periodontal destruction (Borch et al., 2010).

Good oral hygiene is essential both in preventing and treating periodontal disease. Unless plaque is removed and kept under control by tooth brushing, flossing, scaling and polishing, the condition will recur. Improvement in oral hygiene is necessary, but tooth brushing and mouthwashes have effect only above and slightly below the gum level. They are, therefore, ineffective in treating periodontitis, as plaque continues to accumulate within periodontal pockets. Scaling and polishing and sometimes curettage are also required. Surgical removal of the pocket wall and diseased tissue may be needed to facilitate future cleansing, or attempts to regenerate lost periodontal tissues (Elangovan 2010).

Patient education is a necessary component of an effective prevention program. The patient needs to understand the reasons underlying preventive strategies and must be educated about the need for daily plaque control, fluorides, mouth rinses, the risks of dietary sugar, and frequent snacking. Ideally, the individual should be responsible for his/ her oral health (Ohrn et al 2009, Pitts et al 2012).

The current study demonstrated that the periodontal patients had significantly higher GCF, IL-1B and IL-6 concentrations than the group III subjects. These results confirm previous findings reported by Machtei et al 2006, Teles et al 2010, Chaudhari et al 2011, Dutzan et al. 2012, that have clearly demonstrated that inflammatory cytokines such as IL-1 and II-6 have been found significantly higher in diseased as compared to healthy sites, and may play an important role in the pathogenesis of periodontal tissue destruction.

Our results suggest that using the oral hygiene measures with dental treatment for the periodontitis patients was successful. There was a significant decrease in the level of IL-1 and IL-6 in all groups, however, the group with combined approach (group I) has statistically significantly lower levels of interleukins, compared to the other groups. This level has reached down comparable to the group III level. Those findings were in agreement with the reported findings by APL Oliveira et al 2012 detecting a significant reduction in GCF GM-CSF, IL-1 $\beta$ and increases in GCF IL-6 after periodontal therapy, these results could be due to the reduction of GCF volume following successful therapy (Paschalina et al 2012), and was in agreement with previous studies reporting that GCF IL- $1 \beta$ is elevated in periodontitis patients, when compared to healthy 
and gingivitis patients (Hou et al 1995, Engebretson et al 2002), higher in active versus inactive sites (Reinhardt et al 2010) and declines after periodontal treatment (Zhong et al 2007, Rosalem et al 2011, Al-Shammari et al 2001), and that, interleukin-6 is often secreted together with other pro-inflammatory cytokines during the induction of acute phase reactions, GCF levels of IL-6 were elevated during periodontal disease progression in chronic (Geivelis et al 1993) and in refractory periodontitis (Lee et al 1995). Moreover, scaling and root planning were reported to reduce both GCF and IL-1 (Oringer et al 2002).

Heasman et al 1993 reported that during the induction of experimental gingivitis, there was a histological evidence of leukocyte recruitment, vasodilation and epithelial rete peg elongation; and that the observed increases in IL-1 $\alpha$ are consistent with epithelial activation and higher GCF levels of IL$1 \beta$ and with leukocyte margination, diapedesis and vasodilation. Moreover, this cytokine is involved in a variety of cellular activities, including apoptosis, and loss of connective tissue as well as the supporting alveolar bones (Grigoriadou et al 2010). The inflammatory response (represented by IL-1 $\beta$ ) induces MMP-8 production along with other destructive enzymes leading to subsequent connective tissue destruction, and that pro-inflammatory cytokines can stimulate MMP-8 secretion from fibroblast, epithelial and plasma cells was also reported by Sorsa et al 2006, Hanemaaijer et al 1997)

This was in accordance with our histological findings revealing intense inflammatory cell infiltration, dilated blood vessels with edematous epithelial cells and, degenerated and necrotic connective tissue in group III (with no dental or educational treatment). Those histological features, show the greatest improvement in group I (following dental \& educational measures) followed by group II (following dental treatment only), and was lesser in group IV (following educational measures only).
The clinical and histological findings of the present study were in accordance with the ongoing immunohistochemical results demonstrating greatest IL-6 expression in group III (with no dental or educational treatment) which was in agreement with Wilson 2008, who found high infiltration of inflammatory cells with elevated IL-6 expression in the gingiva of periodontitis subjects.

Moderate IL-6 expression was demonstrated in specimens of group II (with dental treatment only) since the inflammatory cells infiltration decreased as compared to group III, the lowest expression was demonstrated in group I (with dental and educational treatment). This could be explained by the study of Sato et al 1999, who concluded that IL-10 was a major regulator in suppressing the inflammatory cells activation; it inhibited their capacity to release IL-6, and led to a consequent inflammation reduction. Further explanation could be given by the study of Engeldhardt 1998 who reported that the weak IL-6 immuno-staining in the treated gingivitis could be due to increase expression of IL-10 produced by keratinocytes and inflammatory cells involved in the healing process. IL-10 was able to inhibit synthesis of inflammatory cytokine IL-6 and also, inhibit the leukocyte migration toward the site of inflammation throughout the healing process.

The clinical, histological, and immunohistochemical data gathered from the ongoing study revealed that oral hygiene measures especially when associated with root planning and scaling help in better chronic periodontitis treatment.

\section{REFERENCES}

1. Al-Shammari KF, Giannobile WV, Aldredge WA, Iacono VJ, Eber RM, Wang HL, Oringer RJ. (2001): Effect of non-surgical periodontal therapy on C-telopeptide pyridinoline cross-links (ICTP) and interleukin-1 levels. J Periodontol.,72: 1045-1051.

2. Alfano MC (1974): The origin of gingival fluid. J Theor Biol.,47 (1): 127-36. 
3. APL Oliveira, M Faveri, L Gursky, MJ Mestnik, M Feres, AD Haffajee, SS Socransky, and RP Teles (2012): Effects of periodontal therapy on GCF cytokines in generalized aggressive periodontitis subjects. J Clin Periodontol., 39 (3): 295-302.

4. Atsushi Saito, 1 Momomi Kikuchi,1 Fumie Ueshima,2 Shinya Matsumoto,1 Hiroki Hayakawa,1 Hitomi Masuda,2 and Takemi Makiishi1 (2009): Assessment of oral self-care in patients with periodontitis: a pilot study in a dental school clinic in Japan. BMC Oral Health, 29: 9-27.

5. Axelsson P, Nyström B, Lindhe J. (2004): The long-term effect of a plaque control program on tooth mortality, caries and periodontal disease in adults. Results after 30 years of maintenance. J Clin Periodontol, 31: 749-757.

6. Azodo CC, Unamatokpa B. (2012): Gender difference in oral health perception and practices among Medical House Officers. Russian Open Med J, 1: 1-4.

7. Bals R, Wang M, Zasloff and Wilson M (1998): The peptide antibiotic LL-37/hCAP-18, IL-6 are expressed in epithelia of the human lung where hcap-18 has broad antimicrobial activity at the airway surface. Proc. Natl. Acad.Sci., 95: 9541-9546.

8. Bertolini DR, Nedwin GE, Brigman TS, Smith DD, Mundy GR. 1(986): Stimulation of bone resorption and inhibition of bone formation in vitro by human tumor necrosis factors. Nature, 319 (6053): 516-8.

9. Borch TS, Holmstrup P, Bendtzen K, Nielsen CH. (2010): In vitro cytokine responses to periodontal pathogens: generalized aggressive periodontitis is associated with increased IL-6 response to Porphyromonas gingivalis. Scand J Immunol., 71 (6): 440-6.

10. Chaudhari AU, Byakod GN, Waghmare PF, Karhadkar VM. (2011): Correlation of levels of interleukin-1 $\beta$ in gingival crevicular fluid to the clinical parameters of chronic periodontitis. J Contemp Dent Pract., 12 (1) :52-9.

11. Daniels RH, Finnen MJ, Hill ME, Lackie JM. (1992): Recombinant human monocyte IL-8 primes NADPH-oxidase and phospholipase A2 activation in human neutrophils. Immunology, 75 (1): 157-163.

12. Delaleu N, Bickel M. (2004): Interleukin-1 beta and interleukin-18: regulation and activity in local inflammation. Periodontol 2000, 35: 42-52.

13. Dewhirst FE, Stashenko PP, Mole JE, Tsurumachi T. (1985): Purification and partial sequence of human osteoblast activating factor: identity with interleukin 1 beta. $\mathrm{J}$ Immunol, 135 (4): 256-8.
14. Dinarello C 2000: Pro-inflammatory cytokines. Journal of allergy Clin. Immunol, 103:11-24.

15. Dinarello CA (2009): Immunological and inflammatory functions of the interleukin-1 family. Annu Rev Immunol, 27: 519-50.

16. Dutzan N, Vernal R, Vaque JP, García-Sesnich J, Hernandez M, Abusleme L, Dezerega A, Gutkind JS, Gamonal J (2012): Interleukin-21 expression and its association with proinflammatory cytokines in untreated chronic periodontitis patients. J Periodontol, 83 (7): 948-54.

17. Elangovan S, Karimbux NJ (2010): Review paper: DNA delivery strategies to promote periodontal regeneration. Biomater, 25 (1): 3-18.

18. Engebretson SP, Grbic JT, Singer R, Lamster IB (2002): GCF IL-1beta profiles in periodontal disease. J Clin Periodontol, 29: 48-53.

19. Engeldhart A, Toksoy M, Gooebeler S, Debus B, Brocker R (1998): Chemokines IL-6, GRO $\alpha$, MCP-1, IP-10, and Mig are sequentially and differentially expressed during phase-specific infiltration of leukocyte subsets in human wound healing. Am. Journal Pathol, 153: 1849-1860.

20. Geivelis M, Turner DW, Pederson ED, Lamberts BL (1993): Measurements of interleukin-6 in gingival crevicular fluid from adults with destructive periodontal disease. $\mathrm{J}$ Periodontol, 64: 980-983.

21. Genco RJ (1992): Host responses in periodontal diseases: current concepts. J Periodontol, 63 (4): 338-355.

22. Grigoriadou $\mathrm{ME}^{1}$, Koutayas SO, Madianos PN, Strub JR (2010): Interleukin-1 as a genetic marker for periodontitis: review of the literature. Quintessence Int, 41 (6): 517-25.

23. Grone A (2002): Keratinocytes and cytokines. Journal of Vet Immunol Imminopathol, 88: 1-12.

24. Golds EE, Mason P, Nyirkos P (1989): Inflammatory cytokines induce synthesis and secretion of gro-protein and a neutrophil chemotactic factor but not $\beta 2$-microglobulin in human synovial cells and fibroblasts. Biochemical Journal, 259 (2): 585-588.

25. Gowen M, Wood DD, Ihrie EJ, McGuire MK, Russell RG (1983): An interleukin 1 like factor stimulates bone resorption in vitro. Nature, 306 (5941): 378-80.

26. Haba D, Teslaru S, Ungureanu D, Hodorog D, Alecu C, Benghiac AG, Zetu L, Ancuţa C, Ancuţa E, Nemţoi A, Iordache C (2011): Evaluation of serum and gingival crevicular fluid C-reactive protein and IL-6 levels in patients with periodontitis and transient ischemic attacks. Rom J Morphol Embryol, 52 (4): 1243-7. 
27. Hanemaaijer R, Sorsa T, Konttinen YT (1997): Matrix metalloproteinase-8 is expressed in rheumatoid synovial fibroblasts and endothelial cells. Regulation by tumor necrosis factor-alpha and doxycycline. J Biol Chem, 272: 31504-31509

28. Heasman PA, Collins JG, Offenbacher S (1993): Changes in crevicular fluid levels of interleukin-1 beta, leukotriene B4, prostaglandin E2, thromboxane B2 and tumour necrosis factor alpha in experimental gingivitis in humans. $\mathrm{J}$ Periodontal Res, 28: 241-247.

29. Honig J, Rordorf-Adam C, Siegmund C, Wiedemann W, Erad F (1989): Increased interleukin-1 beta (IL-1 beta) concentration in gingival tissue from periodontitis patients and healthy control subjects. J Periodontol Res, 24 (6): 362-7.

30. Hou LT, Liu CM, Rossomando EF (1995): Crevicular interleukin- 1 beta in moderate and severe periodontitis patients and the effect of phase I periodontal treatment. J Clin Periodontol, 22: 162-167.

31. Hugoson A, Sjodin B, Norderyd O (2008): Trends over 30 years, 1973-2003, in the prevalence and severity of periodontal disease. J Clin Periodontol, 35: 405-414.

32. Johani HA (2008): Oral Hygiene Practice among Saudi Patients in Jeddah. Cairo Dent J, 24: 395-401.

33. Konig A, Muhlbauer RC, Fleisch H (1988): Tumor necrosis factor a and interleukin 1 stimulate bone resorption in vivo as measured by urinary $(3 \mathrm{H})$ tetracyclin excretion from prelabeled mice. J Bone Miner Res, 3 (6): 621-7.

34. Kwon OJ, Au BT, Collins PD (1994) : Inhibition of interleukin-8 expression by dexamethasone in human cultured airway epithelial cells. Immunology, 81(3): 389-394.

35. Lawlor E, Camp R, Greaves M (1992): Epidermal interleukin $1 \alpha$ functional activity and interleukin 8 immunoreactivity are increased in patients with cutaneous T-cell lymphoma. Journal of Investigative Dermatology, 99 (5): 514-515.

36. Lee HJ, Kang IK, Chung CP, Choi SM (1995): The subgingival microflora and gingival crevicular fluid cytokines in refractory periodontitis. J Clin Periodontol, 22: 885-890.

37. Loe H, Silness J (1963): gingival index (GI). Periodontal disease in pregnancy. I. Prevalence and severity. Acta Odontol Scand, 21: 533-551.

38. Löe H (2000): Oral hygiene in the prevention of caries and periodontal disease. Int Dent J, 50: 129-139.

39. Machtei EE, Oved-Peleg E, Peled M (2006): Comparison of clinical, radiographic and immunological parameters of teeth and different dental implant platforms. Clin Oral Impl Res, 17 (6): 658-65.
40. Magdalena KN, Joanna Z (2015): An Assessment of Oral Hygiene in 7-14-Year-Old Children undergoing Orthodontic Treatment. J Int Oral Health, 7 (1): 6-11.

41. Marsh PD (2012): Contemporary perspective on plaque control. Br Dent J, 212: 601-6.

42. Masada MP, Persson R, Kenney JS, Lee SW, Page RC, Allison AC (1990): Measurement of interleukin $1 \alpha$ and $1 \beta$ in gingival crevicular fluid: implication for the pathogenesis of periodontal disease. Arch Oral Biol, 25 (3): 156-63.

43. Masamatti SS, Kumar A, Baron TK, Mehta DS, Bhat K (2012): Evaluation of interleukin -1B (+3954) gene polymorphism in patients with chronic and aggressive periodontitis: A genetic association study. Contemp Clin Dent, 3 (2): 144-9, 2012.

44. Mombelli A, Lehmann B, Tonetti M, Lang NP (1997): Clinical response to local delivery of tetracycline in relation to overall and local periodontal conditions. J Clin Periodontol, 24: 470-477.

45. Nguyen L, Dewhirst FE, Hauschka PV, Stashanko P (1991): Interleukin-1 beta stimulates bone resorption and inhibits bone formation in vivo. Lymphokine Cytokine Res, 10 (1-2): 15-21.

46. Offenbacher S, Farr DH, Goodson JM (1981): Measurement of prostaglandin in crevicular fluid. J Periodontol, 52: 16-9.

47. Ohrn K, Sanz M (2009): Prevention and therapeutic approaches to gingival inflammation. J Clin Periodontol, 10: 20-6.

48. Oringer RJ, Al-Shammari KF, Aldredge WA (2002): Effect of locally delivered minocycline microspheres on markers of bone resorption. J Periodontol, 73: 835-842.

49. Orozco A, Gemmel E, Bickel M, Seymour GJ (2006): Interleukin-1beta, interleukin-12 and interleukin-18 levels in gingival fluid and serum of patients with gingivitis and periodontitis. J Clin Periodontol, 21 (4): 256-60.

50. Otenio CC, Fonseca I, Martins MF, Ribeiro LC, Assis NM, Ferreira AP, Ribeiro RA (2012): Expression of IL-1, IL6 , TNF- $\alpha$, and iNOS in pregnant women with periodontal disease. Genet Mol Res, 20: 11.

51. Panagakos FS, Aboyoussef H, Dondero R, Jandiniski JJ (1996):. Detection and measurement of inflammatory eytokines in implant crevicular fluid: a pilot study. Int J Oral Maxillofac Implants, 116794: 99.

52. Paschalina G, Evdoxia D, Malamatenia A (2012): Effect of Periodontal Therapy on Crevicular Fluid Interleukin-6 and Interleukin-8 Levels in Chronic Periodontitis. Clinical Study. International Journal of Dentistry, 2012: 8. 
53. Pitts N, Duckworth RM, Marsh P, Mutti B, Parnell C, Zero D (2012): Post-brushing rinsing for the control of dental caries: exploration of the available evidence to establish what advice we should give our patients. Br Dent J, 212 (7): 315-20.

54. Raed AlRowis, Hani S AlMoharib, Abdulrahman AlMubarak, Jagankumar Bhaskardoss, R S Preethanath, Sukumaran Anilm (2014): Oral Fluid-Based Biomarkers in Periodontal Disease - Part 2. Gingival Crevicular Fluid. J Int Oral Health, 6 (5): 126-135.

55. Raghavendra NM, Pradeep AR, Kathariya R, Sharma A, Rao NS, Naik SB (2012): Effect of non-surgical periodontal therapy on gingival crevicular fluid and serum visfatin concentration in periodontal health and disease. Dis Markers, 32 (6): 383-8.

56. Reinhardt RA, Stoner JA, Golub LM, Lee HM, Nummikoski PV, Sorsa T, Payne JB (2010): Association of gingival crevicular fluid biomarkers during periodontal maintenance with subsequent progressive periodontitis. J Periodontol, 81: 251-259.

57. Rosalem W, Rescala B, Teles RP, Fischer RG, Gustafsson A, Figueredo C (2011): Effect of Non-Surgical Treatment on Chronic and Aggressive Periodontitis: Clinical, Immunological and Microbiological Findings. J Periodontol, 81: 251-259.

58. Sabatini M, Boyce B, Aufdemorte T, Bonewald L, Mundy GR (1988): Infusions of recombinant interleukins 1a and $1 \beta$ cause hypercalcemia in normal mice. Proc Natl Acad Sci USA, 85 (14): 5232-9.

59. Saleh F, Dyer PV (2011): A questionnaire-based survey of patient satisfaction with dental care at two general dental practice locations. Prim Dent Care, 18: 53-8.

60. Sato Y, Oshima T, Kondo T (1999): regulatory role of endogenous IL-10 in cutaneous inflammatory response of murine wound healing. Biochem. Biophys. Res. Comm, 265: 194-199.

61. Siamak Y, Afshin K, Mojgan P (2013): Comparison of Interleukin-1 $\beta$ Levels in Gingival Crevicular Fluid and Peri-Implant Crevicular Fluid and Its Relationship with Clinical Indexes. J Dent (Tehran), 10 (1): 1-9.

62. Silness J, Loe H (1964): Periodontal disease in pregnancy. II. Correlation between oral hygiene and periodontal condtion. Acta Odontol Scand, 22: 121-135.

63. Smith WB, Gamble JR, Clark-Lewis I, Vadas MA (1993): Chemotactic desensitization of neutrophils demonstrates interleukin-8 (IL-8)-dependent and IL-8-independent mechanisms of transmigration through cytokine-activated endothelium. Immunology, 78 (3): 491-497.
64. Sorsa et al T, Tjäderhane L, Konttinen YT (2006): Matrix metalloproteinases: contribution to pathogenesis, diagnosis and treatment of periodontal inflammation. Ann Med, 38: 306-321.

65. Stashenko P, Dewhirst FE, Perso WJ, Kent RL, Ago JM (1987): Synergistic intractions between interleukin 1, tumor necrosis factor, and lymphotoxin in bone resorption. $\mathrm{J}$ Immunol, 138 (5): 1464-8.

66. Stashanko P, Jandinski J, Fusjioshi P, Rynar J, Socronski SS (1991): Tissue levels of bone resorptive cytokines in periodontal disease. J Periodontol, 62 (8): 504-6.

67. Stashenko P, Dewhirst FE, Rooney ML, Desjardins LA, Heeley JD (1987): Interleukin-1 $\beta$ is a potent inhibitor of bone resorption in vitro. J Bone Miner Res, 2 (6): 559-65.

68. Tasi CC, Ho YY and Chen CC (1995): Levels of interlukin-1 beta and interlukin-8 in gingival crevicular fluid in adult periodontitis. J Periodontal, 66: 850-9.

69. Teles RP, Gursky LC, Faveri M, Rosa EA, Teles FR, Feres M (2010: Relationships between subgingival microbiota and GCF biomarkers in generalized aggressive periodontitis. J Clin Periodontol, 37 (4): 313-23.

70. Toker H, Marakoglu I, Poyraz O (2006): Effect of meloxicam on gingival crevicular fluid IL-1beta and IL1 receptor antagonist levels in subjects with chronic periodontitis, and its effects on clinical parameters. Clin Oral Investig, 10 (4): 305-10.

71. Uitto VJ (2003): Gingival crevice fluid: an introduction. Periodontol 2000, 31: 9-11.

72. Vick VC, Harfst S (2000): The Oral Risk Assessment and Early Intervention System -A clinician's tool for integrating the bio/psycho/social risk into oral disease interventions. Compend Contin Educ Dent Suppl, 30: 57-64.

73. Vinayak VM, Gunjiganur VG, Dhoom SM (2014): Effects of scaling and root planing with or without a local drug delivery system on the gingival crevicular fluid leptin level in chronic periodontitis patients: a clinico-biochemical study. J Periodontal Implant Sci, 44 (3): 118-125.

74. Wilson F (2008): Effect of ultrasonic debridment using a chlorhexidine irrigation on circulating levels of lipopolysaccharides and IL-6. Journal of Clinical Periodontology, 34: 415-419.

75. Xynogala I, Pepelassi E, Perrea D, Agrogiannis G, Pantopoulou A, Patsouris E, Vrotsos I (2012): Adiponectin and interleukin-6 levels in insulin-treated diabetic rats with experimental periodontitis. Braz Oral Res, 26 (1): 71-6.

76. Zhong Y, Slade GD, Beck JD, Offenbacher S (2007): Gingival crevicular fluid interleukin-1beta, prostaglandin E2 and periodontal status in a community population. J Clin Periodontol, 34: 285-293. 